„Śląskie Studia Polonistyczne” 2021, nr 2 (18) ISSN 2353-0928

https://doi.org/10.31261/SSP.2021.18.13

Published:

16.08 .2021

\section{Michał Sowiński}

JAGIELLONIAN UNIVERSITY

(iD $h t$ tps://orcid.org/0000-0003-1613-0662

The Accursed Economy of Literature*

\begin{abstract}
In this article, the author explains the connection between literature and economy on a philosophical level, especially in case of logic of exchange and concept of mimesis in novels. Basic tools for his arguments are derived from Georges Bataille's concept of Accursed Economy (from the essay "The Accursed Share"). The French philosopher argues that in our everyday reality we use logic imposed on us by capitalism, which means that the value of everything is measured by its utility and, at the same time, values of all things can easily be accumulated. Because of that blind belief something important is omitted - surplus, a particle which does not fit into the global system of exchange. In the author's opinion this phenomenon (and all its consequences) can be used to interpret the novel Bartleby, the Scrivener by Herman Melville, showing the main character's activities (or their lack) in different contexts. This interpretation also proves the usefulness of applying some tools and terms from the language of economics into literary studies.
\end{abstract}

Keywords: economy of literature, mimesis, Melville, Bataille

In The Accursed Share, Georges Bataille argues that any and all forms of economy - not only human economy, but ecosystems as a whole - are merely derivative from a much greater economy, which he calls solar economy. Solar radiation led to the origin of life on Earth. This, naturally, includes human activity and the rise of culture and civilisation. Admittedly, this planet would be an icy and empty space without light. That said, it is not so much solar energy that is crucial to life as life's ability to store and accumulate energy. The resulting energy surplus enables development and expansion. Growth would be impossible if energy was instantaneously expended to cover the current needs of living organisms or their systems. It is this excess energy that is at the very core of Bataille's investigations.

According to Bataille, solar economy, which predetermines all derivative forms of economy, is crucial to the understanding of human activity as a whole. Its defining feature is unilaterality: "solar radiation stands out as unilateral: it loses itself without

\footnotetext{
* The research was funded by the National Science Centre based on decision
} no. UMO-2012/05/N/HS2/02691.

The Accursed Economy of Literature 
restraint and gains nothing in return" $(1976,10)$. While solar energy provides the Earth with unlimited resources, earthly economy, which is based on solar economy, cannot develop without end. Growth invariably comes to a halt, and when this happens, waste, or pointless expenditure, becomes a necessity. When an individual (or the whole system) "can no longer expend constant energy surplus into growth, excess continues, but energy rediscovers its primordial freedom. Life, which can no longer make a useful and constant investment of energy, begins to waste it." (Bataille 1976, 12).

This succinct formula encapsulates the idea behind The Accursed Share - in a nutshell, growth must invariably be counterpoised by lavish waste. Without overly simplifying matters, anything that lives on Earth is a consequence of friction between the two opposing movements. In a style of his own, Bataille seeks to create a total theory with which to describe the system of relations in the world. Accordingly, his considerations on culture and civilisation are preceded by an extended discussion of wildlife. Bataille follows in the footsteps of Darwin when he argues that the process of evolution saw the emergence of ever so complex organisms. It followed a trajectory from primitive bacteria, which consumed energy almost without waste, to the tiger, which symbolises the extreme waste of energy.

As he sketches the principle underlying the world from the origin of life, Bataille goes against the grain of a universal dogma whereby expenditure for growth is the only way life could function on Earth. He points out that all previous reflections on general economy failed to examine waste as the key element of the system. This is because waste in the Western world is seen as something almost uniquely deplorable.

\section{Everything is Surplus}

For Bataille, anything that exists is a form of energy surplus. The process of accumulation can take a variety of forms ranging from exuberant wildlife to extremely refined works of art (including literature and "textual activity" as a whole). ${ }^{1}$ Since energy growth is constant, energy must necessarily find a release. Naturally, Bataille's "accursed share" is the process of growth in reverse; it is energy that must be expended in an unproductive way. In other words, his aim is to "invert a customary point of view" whereby "the globe must lose what it cannot contain"

1 In L'économie à la mesure de l'univers, which serves as an introduction to the French edition of The Accursed Share, Bataille emphasises the paradoxical nature (or, in his idiom, perversity) of his own pursuit, i.e., writing a treatise on waste in a book form, which is the very epitome of accumulation. 
(Bataille 1976, 13). Forced to accumulate ever greater volumes of energy, the human plays a unique role in this system. Bataille argues that most of the activities that are customarily regarded as the quintessential features of humanity belong in the realm of loss and waste.

In Preface, Bataille writes: "I had to try in vain to make clear the notion of a 'general economy' in which the 'expenditure' (the 'consumption') of wealth, rather than production, was the primary object" $(1988,9)$. This conception seems to be particularly interesting in the context of this treatise in that it primarily describes various forms of cultural production, most notably literature: "Even what may be said of art, of literature, of poetry has an essential connection with the movement I study: that of excess energy, translated into the effervescence of life" (Bataille $1988,10)$. Bataille's approach to literature is intriguing inasmuch as it withdraws literature from the realm of purely aesthetic or existential reflection: text, however defined, ceases to perform its expressive or impressive functions; instead, it becomes one of the major elements in Bataille's peculiar understanding of economy.

Each and every energy surplus must be put to use: either into the growth of the system or into its dissipation if growth is no longer possible and the system has reached its critical point (no "resources" or "space" available). According to Bataille, "the ground we live on is little other than a field of multiple destructions" $(1988,17)$. He argues that dissipation may take two forms: either commendable or catastrophic. The latter involves armed conflicts and bloodshed, which occur in cycles throughout the history of humankind. For energy is a destructive force when unexpended. That is why culture needs, as it were, safety valves: when faced with the war-or-waste alternative, one would obviously choose the latter. For Bataille, the construction of the Pyramids is the very epitome (if not the symbol) of such activity. These monuments had no immediate and useful purpose and yet they required an enormous expenditure of energy, which could perhaps serve other and more useful imperial purposes. It is no coincidence that Bataille chooses ancient Egypt as his illustrative example. The solar theme, which recurs throughout The Accursed Share, is deeply rooted in primitive solar cults that depict the Sun positively, as a hero and a giver. According to Bataille, it was not until Christianity and capitalism had blended into one that the cult of accumulation emerged and dissipation and excess were condemned as sinful. "In former times value was given to unproductive glory, whereas in our day it is measured in terms of production: Precedence is given to energy acquisition over energy expenditure" $(1988,29)$. In this light, all inherently romantic forms of protest against the world of bourgeois values (and as such capitalist values of accumulation) seem a safety exit. 
Bataille addresses these values in the subsequent sections of his book.

This useful uselessness is at the very heart of Bataille's thinking; it also underlies my concept of the economy of literature terminology. It is an example of a stand against the dictates of usefulness - like an unbreakable grain getting into the smoothrunning gears of accumulation and exchange. Its purpose is to salvage the irreducible remnant of meaning, which defines the literary essence of a text. What follows is that such a text is no longer a vessel in which to deposit meaning (or what the theory of communication calls messages).

Religion, a recurring theme in The Accursed Share, is depicted by Bataille as a forgotten metaphysical tradition which makes the world transcend the paradigm of usefulness and accumulation. This peculiar understanding of religion is best evidenced in the fact that it refuses to accept Protestantism as religion. For Protestantism, argues Bataille, has brought the ultimate departure from metaphysics and a shift towards the material logic of capitalist development.

Bataille makes several references to Max Weber's seminal treatise The Protestant Ethic and the Spirit of Capitalism. The general premise of Weber's book, namely, that the rise of capitalism was particularly rapid in the Protestant form of life (in contrast to its Catholic manifestations), has attracted widespread criticism. However, his selected insights remain valid for the analysis of capitalist ideology and the symbolic field that paved the way for the development of capitalism, given the fact that capitalism thrived in a belt stretching from England to northern Italy. Weber's definition of capitalism is convergent with that of Bataille's: for the former, the drive for profit is something natural and present from the very rise of civilisation. Modern capitalism brings a significant correction to this picture. "Capitalism may even be identical with the restraint, or at least a rational tempering, of this irrational impulse" (Weber 2005, xxxi). For this reason, it perfectly intermeshed with the concept of Christian askesis, most notably in its Protestant form. With some simplification, this is not so much about self-mortification as about compliance with the extreme dictates of usefulness. These dictates are premised on the belief that the world was given to humankind by God for a particular purpose (and not for eternity) and that any and all types of activity must necessarily be subordinated to the concern for the multiplication of wealth. The condemnation of waste and opulence as sinful is naturally a reverse of such ideology. Weber also argues that askesis in its capitalist form quickly loses its religious pedigree and morphs into secular ideology, which is best epitomised by Benjamin Franklin's celebrated "sermon" on time as money: "He that kills a breeding-sow, destroys all her off- 
spring to the thousandth generation. He that murders a crown, destroys all that it might have produced, even scores of pounds" (Franklin 1840, 15).

This digression about the enmeshment of capitalism with Protestantism is necessary for a better understanding of Bataille, who considers religion (or the return of metaphysics he was trying to instigate) to be something opposite. This is best expressed in his enthusiastic (and sometimes disturbing) depictions of Aztec religion and its spectacular offerings. "They were just as concerned about sacrificing as we are about working" (Bataille 1988 , 46). This sacrificial economy permeated every sphere of life, including war, whose purpose was consumption rather than conquest. According to Bataille, this could shed a new light on the Aztec society as an anti-military one. The sacrificial ritual, which mediates the logic of excess with the order of usefulness, opens up its participants to the experience of excess while giving them a minimum degree of safety. The rituals described by Bataille are filled with absurd and unnecessary violence, which is nonetheless limited so as not to break loose into the whole of society. Purposeless and arbitrary, it is far from accidental. "Sacrifice is heat, in which the intimacy of those who make up the system of common works is rediscovered" (Bataille 1988, 46). That said, this system of activity has nothing to do with working or "enterprise"; it is chiefly concerned with preserving the commonality and, paradoxically, with salvation.

Arguably, we are now touching upon the most important paradox. For Bataille, the offering, that is, the destruction or consumption of those things that could serve a useful purpose is, at the same time, the only form of salvaging the offering. The sacrificed object thus becomes "the accursed share." "The victim is a surplus taken from the mass of useful wealth. And he can only be withdrawn from it in order to be consumed profitlessly, and therefore utterly destroyed. Once chosen, he is the accursed share, destined for violent consumption. But the curse tears him away from the order of things; it gives him a recognizable figure, which now radiates intimacy, anguish, the profundity of living beings" (Bataille 1988, 59). In losing himself, the victim acquires himself. The excessive and pointless offering leads to the transfiguration of things, which are now consigned to a different economic order.

\section{Potlatch}

For Bataille, the offering is very much akin to potlatch, namely, the ritual destruction of useful goods. This can be understood very broadly, since Aztec mass offerings from prisoners of war are also a form of potlatch. Potlatch is similar to the offering in 
that it is quintessentially defined by its paradoxical impossibility. That is why Bataille errs on the side of caution here. In his view, many of our daily activities share certain traits with potlatch, e.g. sumptuous feasts, in which most of the food is wasted, or something more contemporary: formal functions and their expensive refreshments, which are neither tasty nor wholesome. However, such activities cannot be treated as a fully-fledged potlatch (and, as such, potlatch proper) because, ultimately, they are intended to be useful and profitable, e.g., they build the prestige of those who waste the goods by elevating their position as someone wealthy (or by expressing their aspirations to this position). Similarly, Bataille is reluctant to acknowledge the classical examples of potlatch, e.g. various festivals of waste observed by Native American tribes (often quoted by anthropologists and cultural scholars). In their own right, these may be intriguing cases of the perverse approach to the economy of the useful, but they are nonetheless different from "the accursed share" in that they use a slightly different language to build the social and symbolic capital of those who give a potlatch. "No one can both consume wealth and increase it" if they wish to break away from the economy of the useful (Bataille 1988, 74).

The fact remains, however, that potlatch (even if it is never fully possible, which makes it similar to the offering) is a practice of key importance to the economic system designed by Bataille. Its "meaning is in the fact that it withdraws wealth from productive consumption" (1988, 75). As such, potlatch contests "the order of things" and its logic. A refusal to participate is also a form of potlatch. Since both potlatch and the offering withdraw the offered or destroyed things from a particular economic system, a refusal to participate is a form of offering/potlatch made from oneself or one's life. Bataille says that both a poor man who is impervious to worldly riches (this, however, cannot be linked to askesis motivated by religion; this type of askesis was discussed earlier, and it is the very opposite of the poor man's attitude) and those who squander their potential epitomise in equal measure this paradoxical activity whereby one refuses to participate. Herman Melville's Bartleby, the scrivener, is one of the greatest literary characters that are representative of this attitude. His "I'd prefer not to" proves to be the fullest realisation of the postulates presented in this article.

\section{What Happened in Wall Street?}

Melville's novella begins with a short introduction by the narrator, the owner of a law firm; he explains who copyists, the characters in his story, are. As suggested by the novella's subtitle "A Story of Wall Street," these people work in the very eye 
of the capitalist storm. "I am one of those unambitious lawyers who [...] in the cool tranquillity of a snug retreat, do a snug business among rich men's bonds and mortgages and title-deeds" (Melville 2002, 4). People who perform daily and tedious work and render a smooth and reliable service to the big capital must have a peculiar mental constitution. Their poor ambition is one thing, but the narrator himself mentions prudence and method as his primary virtues, which earned him praise from his superiors. The law chambers in which copyists work are more akin to an ascetic hermitage. Located in the city centre, they are also utterly sequestered, which is intended to improve the focus and attention of the employees while safeguarding the place and making it impenetrable. This is best represented by the metaphorical description of an outside view from the office. "[...] My windows commanded an unobstructed view of a lofty brick wall, black by age and everlasting shade, which wall required no spy glass to bring out its lurking beauties [...]" (Melville 2002, 5).

The law chambers work as an isolated system. Therefore, it is vital to keep their inner equilibrium. Before the advent of Bartleby, the narrator had two copyists in employment and one office-boy called Ginger Nut, who entertained a much lower station in the hierarchy of the workplace. Apart from cleaning, his role was to serve the other two men and bring them cakes (hence his nickname). This indulgent tone and extremely limited competences are quite self-explanatory. However, there could be more complex reasons behind this particular system. In symbolic terms, the boy acts as a liaison between the chambers and the outside world. As a runner, or "office-boy," he has nothing, in fact, to do with the inner workings of his workplace. He is out of the picture when it comes to preserving the dynamic equilibrium of the office. This equilibrium is vital for its functioning.

The caricature symmetry between Turkey and Nippers (thus are nicknamed the other two men) is a case in point. These two peculiar characters, who are a combination of temperament (an internal trait) and chronic indigestion (an external trait), complement each other like day and night in a closed twenty-fourhour cycle. Nippers has his displays of nervosity in the morning, but he finally calms down around noon. Conversely, Turkey becomes increasingly anxious as the day wears on. "Their fits relieved each other like guards. When Nippers' was on, Turkey's was off; and vice versa. This was a good natural arrangement under the circumstances" (Melville 2002, 8).

A watershed, or a departure from this smooth-running and efficacious (and also self-regulating) ecosystem, comes with the advent of Bartleby, a new and inscrutable employee. Right from the outset, he is offered a workstation of his own. With no space available in the copyists' room, he is given a desk in his superior's 
office. That said, the desk is separated from the rest of the room by a partition: Bartleby remains unseen, but verbal communication continues.

He passes his first days and weeks on the job working extremely hard. He also shows much determination is his painstaking drafting and copying of documents. However, the way he works proves to be disturbing to his superior: "I should have been quite delighted with his application, had he been cheerfully industrious. But he wrote on silently, palely, mechanically" (Melville 2002, 10). Thus, the first dissonance occurs even before Bartleby utters his celebrated "I would prefer not to." He causes a disruption to the system with the very way he works, which leaves little to be desired from the pragmatic point of view. That said, the unwritten law of the chambers stipulates that sacrifice and diligence must be counterpoised by enthusiasm and cheerfulness. Interestingly, the same rule applies to the contemporary corporate workplace.

Only a moment later, the newly employed scrivener uses his ultimate weapon: he utters "I would prefer not to," which is said neither as a denial nor negation, but as a refusal to participate, a rejection of communication (or even its destruction). Yet, before I move on to the linguistic and economic implications of his gesture, let us follow the story of Bartleby to the very end. On the first hearing "I would prefer not to," Bartleby's superior is mostly surprised. "This is very strange, thought I. What had one best do?" (Melville 2002, 10). Naturally, one could easily furnish a realistic reading of this parable whereby no response other than the immediate dismissal of the recalcitrant employee is possible. However, as suggested above, Bartleby, the Scrivener is not a sociological case study of the clerks working in New York, but rather a parable on the modern system of symbolic economy, most notably in the context of language. The fact that Melville's short novel is set in Wall Street demonstrates that his intuitions were very much similar to those of Bataille, who offered a general view on economy and also described its particular variants, e.g., the economy of communication and that of cash flow, as convergent to some degree.

“'Why do you refuse?' 'I would prefer not to."' (Melville 2002, 12). This brief exchange encapsulates the principal issue described in the novel. The same issue is central to my interpretation. "But there was something about Bartleby that not only strangely disarmed me, but in a wonderful manner touched and disconcerted me. I began to reason with him" (Melville 2002, 12). Bartleby is both irritating and intriguing; he cannot be simply shrugged off as something unimportant. His presence is irreducible precisely because he does nothing and because he neither agrees nor disagrees with his superior. In the subsequent sections of the story, 
Bartleby becomes "a perpetual sentry in the corner" (Melville $2002,13)$. He ceases to perform any and all life activities, even the most basic ones. He feeds on ginger cakes only (he eats no meat or vegetables). To some extent, as is rightly pointed out by the narrator, he accepts a condiment rather than real food; he eats something superfluous, a supplement, as it were, which imparts flavour but is not very nutritious in itself. The issue escalates when Bartleby, who already lives in the chambers and has a separate set of keys to the office, locks himself from the inside and leaves the key in the lock. In so doing, he prevents others from entering; he becomes a porter who decides whom to grant and whom to deny access to the office. The principal responds to this mounting disruption in his workplace with a tremendous amount of patience and empathy. He is so patient and understanding that it may actually provoke some second thoughts as to his motivations. His being indulgent, an interpretation which almost immediately springs to mind, is only one possible reading. His visibly nervous response may also hint at something more. He seeks to rationalise Bartleby's behaviour, as he cannot afford to let Bartleby's antics become a fully accepted stance. "Charity often operates as a vastly wise and prudent principle - a great safeguard to its possessor," (Melville 2002, 25) says the narrator. This is the key issue at stake: charity which he strives to show to his employee, even when the latter stops working at all, is primarily there to banish the thought that Bartleby may not be a poor disadvantaged loser and his actions are intended to achieve an entirely different goal.

When the situation with Bartleby becomes totally unbearable, the owner of the law chambers decides to kick him out. Bartleby, who in fact has completed no task whatsoever, receives his due payment. His superior even offers him a large tip as compensation. The copyist refuses to accept the money and continues his inactivity. His obstinacy makes the entire office move premises, the official reason being to move closer to the City Hall. As a result, Bartleby gains the upper hand in this complicated skirmish. Armed with weapons such as charity and rationalisation, the system epitomised by the law chambers is forced to retreat. Nevertheless, Bartleby loses the war when he eventually finds employment at the Dead Letter Office, the only place in the world where his refusal to communicate turns into his asset. His task there is to annihilate the words of others which for some reason could not reach their recipients. The narrator describes Bartleby's new engagement with the following words which also happen to conclude the entire story: "On errands of life, these letters speed to death. Ah Bartleby! Ah humanity!" (Melville 2002, 34). Thus, even those who choose radical resistance and refuse to act in any way whatsoever will find their place in the system. 
What is Bartleby's strategy and why is it relevant to my examination of Bataille's economy? Melville's scrivener embodies resistance against Bataille's economy of total exchange. His act of transgression is targeted against a world utterly subordinated to the logic of exchange and accumulation. The world that Bartleby enters lies at the very core of global economy, at the very heart of capitalism. The task of the employees in this system is to enable its smooth and reliable operations. The scrivener is entrusted with the task of copying documents without any deviation or interference on his part, the least of which can have negative consequences. The tiniest of errors becomes a spanner thrown in the fast-running gears of general economy. As such, it is immediately detected and removed, and the culprit is denied the right to continue his activity. Bartleby's strategy is far more cogent and sinister. He makes no effort to fight the system; instead, he remains radical in his doing nothing, as a result of which he can stay inside. In so doing, he commits a dangerous transgression.

He also uses language as his primary weapon. This strategy is particularly relevant to my investigations. Deleuze argues that Bartleby's celebrated formula, namely, "I would prefer not to," is agrammatical $(1997,68)$. Grammatically correct yet unusual, it stands as the limit of possible linguistic expression. "Murmured in a soft, flat, and patient voice, it attains to the irremissible, by forming an inarticulate block, a single breath" $(1997,68)$. Bartleby repeats the phrase many times in many contexts, but he never changes its form. Deleuze suggests that the formula burgeons and proliferates - it heralds the arrival of the unimaginable or unrepresentable, "as if he had said every thing and exhausted language at the same time" (1977, 70). With each and every recurrence of the phrase, the office slowly seeps into madness, which affects everyone but Bartleby, who continues to be immovable, as if he were in the very eye of the storm of his own making.

As demonstrated by Deleuze, at some point, the formula starts to involve the very act of copying. "All particularity, all reference is abolished. The formula annihilates 'copying,' the only reference in relation to which something might or might not be preferred" (Deleuze 1997, 71). Bartleby uses language, which he also ravages, to infect the whole reality around him with nothingness. Deleuze goes so far as to say that Bartleby's goal is to destroy the English language: to penetrate its foreignness and bring it to the surface. Bartleby's arrival marks the advent of the foreign and the unintelligible. This is also precisely why his superior goes to great lengths to talk him over and drown him out. Bartleby's task is being accomplished at an interface of language and economy. He seeks to destroy language by renouncing exchange; he refuses to accept his salary (which he has not even earned) and to 
participate in the copying activity, which keeps the office going. Bartleby announces the long silence, says Deleuze (see: 1997, 73). Unbearable, this silence belongs to the same category as Bataille's sacrificial offering, as it breaks away with the logic of accumulation and growth.

Bartleby, the scrivener, is a copyist inasmuch as he copies other copyists: he purports to be only a small cog in the machine, but he, in fact, fails to be one, which may lead to a noticeable and perceptible failure or stoppage of the system. According to Deleuze, he severs language from all reference: "It implies that Bartleby stop copying, that is, that he stop reproducing words; it hollows out a zone of indetermination that renders words indistinguishable, that creates a vacuum within language [langage]" (1977, 73). This state of hollowness resembles Bataille's act of sacrificial offering (or the act of restoring metaphysics), which also severs the ties between reality and language: it carves out a breach where things could finally be seen for what they are, insofar as there is language that makes their perception possible (the same paradox).

Naturally, Bartleby is not the only literary protagonist who violates language. Literary works abound in similar characters who remain doggedly silent and, in so doing, destabilise reality. ${ }^{2}$ Melville's novella is unique in that it brings a radical nihilist to the realm of economy. This, however, is not intended to create a vivid setting only. The narrative harnesses the mechanisms of economy for the purpose of annihilating language. Such an act has also its positive dimension. In general terms, it is expressive of a modernist dream where the veil has finally dropped and the view of the other side or the immediate experience of reality is made possible. In other words, Bartleby, the Scrivener is a literary attempt at creating a new and paradoxical model of the economy of representation. As such, this model is also impossible to achieve. In these circumstances, Bartleby becomes an agent of language, who annihilates the very medium he uses and makes boreholes in the semiotic crust deposited around reality. In a metaphorical language of his own, Deleuze calls it a shift from the model of reference to the model of preference. For Bartleby's formula harnesses speech acts that refer neither to themselves (self-referential) nor to reality (referential). This marks a departure from dualism, which could be described with a number of oppositions such as poetry vs. prose (Leśmian, Mallarmé), poetic function vs. cognitive function (Jakobson), myth vs. reality (Schulz), etc. In other words, what we are dealing

2 Enrique Vila-Matas offers a spectacular litany of these characters in his Bartleby $\mathcal{E}$ Co., where he tracks down many different bartlebys (the lowercase intended). See: Vila-Matas 2000. 
here with is the economy of gift-giving in reverse, i.e. inverted excess which breaks away from the logic of exchange and permanent equivalence not so much with ecstatic and purposeless gift-giving (Barthes's "I love you") as with the voiding of reality of meaning or piercing a black hole in it. This black hole becomes an impossible promise of insight, a kind of gate leading to the other side (Kafka).

Bataille's eccentric theory of total economy, which stages a permanent conflict between the powers of accumulation and the powers of waste, may offer intriguing applications to the study of literature. On the one hand, it allows the placing of a text in a broader economic context. On the other, it shows that any and all symbolic activity can be described in economic terms. Melville's novella is driven by the same kind of tension that is at the very heart of Bataille's theory, which, in turn, is an attempt at developing a new model of the economy of representation a model which goes against the grain of established tradition. It is important to note that it does so both at the narrative and the linguistic and stylistic levels. As such, Bartleby, the Scrivener is a perfect example of the benefits offered by the merging of these two languages, where new conceptual frameworks develop and many things can be examined from a new and different angle.

\section{Bibliography}

Bataille, Georges. 1976. Oeuvres complètes. Tome VII: La Part maudite. L'économie à la mesure de l'univers. La limite de l'utile (fragments). Théorie de la religion. Conférences 1947-1948. Annexes. Paris: Gallimard.

Bataille, Georges. 1988. The Accursed Share: An Essay on General Economy. Translated from French by Robert Hurley. New York: Zone.

Deleuze, Gilles. 1997. "Bartleby; or, The Formula." In Essays Critical and Clinical, 68-90. Translated from French by Daniel W. Smith and Michael A. Greco. London: Verso.

Franklin, Benjamin. 1840. "Necessary Hints to Those That Would Be Rich." In The Works of Benjamin Franklin. Vol. 2, edited by Jared Sparks. Boston: Hilliard, Grey, and Company.

Melville, Herman. 2002. "Bartleby, the Scrivener. A Story of Wall Street." In Melville's Short Novels: Authoritative Texts, Contexts, Criticism, selected and edited by Dan McCall, 3-34. New York; London: W. W. Norton \& Company.

Vila-Matas, Enrique. 2000. Bartleby \& Co. Translated from Spanish by Jonathan Dunne. London: New Directions.

Weber, Max, 2005. The Protestant Ethic and the Spirit of Capitalism. Translated from German by Talcott Parsons. London: Routledge. 